\title{
Tillage Effect on Soil Moisture Storage and Wheat Yield on the Vertisols of North Central Highlands of Ethiopia 1Fassil Kebede and ${ }^{2}$ Eyebru Bekelle
}

\begin{abstract}
Vertisols are one of the agriculturally important soils in Delanta Dawunt, north central highlands of Ethiopia, for peasant farmers as almost all the cereal, soil and forage crops are grown on them. However, waterlogging during the growing season impedes the performances of cereal crops. It is crucial to seek for cost effective means to mitigate waterlogging for increased production. Hence, a field experiment was conducted to observe effectiveness of tillage on draining excess soil water. To this effect treatments, i.e., 'flat seedbed, 'traditional drainage system' (Shurube), 'broadbed and furrow with $100 \mathrm{~cm}$ (BBF-100 cm)' and 'broadbed and furrow with $80 \mathrm{~cm}^{\prime}(B B F 80 \mathrm{~cm})$ were arranged in a randomized complete block design with three replications on $6 \mathrm{~m}$ by $4 \mathrm{~m}$ plot. The study revealed that $B B F-100 \mathrm{~cm}, B B F-80 \mathrm{~cm}$ and traditional drainage system significantly increased the grain yield of wheat by $51.4 \%, 41.6 \%$ and $11.2 \%$ compared to the control, respectively. Therefore, this study recommends ' $B B F-100 \mathrm{~cm}$ followed by BBF-80 cm to fight against seasonal waterlogging and to boost wheat production in the North central highlands of Ethiopia.

Key words: Broadbed and furrow with $100 \mathrm{~cm}$, Broadbed and furrow with $80 \mathrm{~cm}$, Flat seedbed; Traditional drainage System; Tillage, Vertisols; Wheat
\end{abstract}

\section{Introduction}

$\mathrm{E}$ thiopia ranks third in Vertisols abundance in Africa after the Sudan and Chad (Berhanu, 1985). An estimated 7.6 million ha of Ethiopian Vertisols are located in the highlands above $1500 \mathrm{~m}$ a.s.l. and on higher elevations ( $>2500 \mathrm{~m}$ a.s.1.) in temperate ecosystems (Berhanu, 1985; Jutzi and Mesfin, 1987; Lakew et al., 2005; Teklu et al., 2006). About $25 \%$ of those occurring in the highlands are believed to be cultivated (Berhanu, 2000, Abate et al., 1993). The highest coverage of Vertisols in the country is found in Oromiya region (47.6\%) followed by Amhara sharing $(25.2 \%)$ or 3.2 million ha of the total (ARDB, 2005). Among the 113 Woreda's in the Amhara Region, Vertisols are found only in 79 Woredas of which Delanta Dawunt Woreda is one (ARDB, 2005) wherein this research was conducted.

Wheat is the most important single crop in the area followed by lentil. It is also the first crop, which accounts $26.6 \%$ and 5.6 $\%$ of the cultivated land in Meher and Belg cropping season in the study area, respectively. Seasonal water logging is one of the major agricultural problems during the main rainy season of the north central highlands of Ethiopia. As a result, early planting is prohibited with traditional management system, which in its turn will reduce the length of the growing cycle. Apparently, seeking for a means to reverse the limitation is pragmatic. Amongst the technological options, broad bed furrow (BBF) had gain much attention for draining the excess water out of the field thereby production is increased (ARDB, 2005). Besides, local farmers traditionally grow relatively waterlogging resistant crop, Enzosh Synde, a 'local wheat variety' which also tolerates frost. Thus, this study was conducted to examine effect of the BBF system on the productivity of Enzosh Synde by entwining the BBF technology with the nature of a local water logging resistant wheat variety.

\section{Materials and Methods Study area}

Delanta Dawunt woreda is located in North West part of Wollo and administrated under North Wollo administrative Zone (Fig.1). Currently, Delanta Dawunt has a population of 200,000 with a landmass of $1678.6 \mathrm{~km}^{2}$. The altitude of the Woreda ranges between $1700 \mathrm{~m}$ a.s.l in river valleys to 3500 $\mathrm{m}$ a.s.l at Mountains. The experimental site was selected based on the criteria of area coverage of waterlogging problems, population density and proximity when the comparison made among other hamlets.

\footnotetext{
${ }^{1}$ Department of Land Resource Management and Environmental Protection, Mekelle University, Mekelle, Ethiopia. fassil@ethionet.et

${ }^{2}$ District Disaster Prevention and preparedness Commission, North Wello Zone, Delanta Dawunt Woreda, Ethiopia
} 
The climatic data of the study area for the years 1995 to 2005 indicates that the mean annual rainfall of the area $776.7 \mathrm{~mm}$ of which $72.2 \%$ is received during the main growing season (Kiremet) i.e. from June 20 to
September 10. July and August alone contribute more than $65.6 \%$ to the annual rainfall (Fig.2). The periods from October to May and the first 20 days of June are virtually dry.

\section{NORTH WOLOBASEMAP}

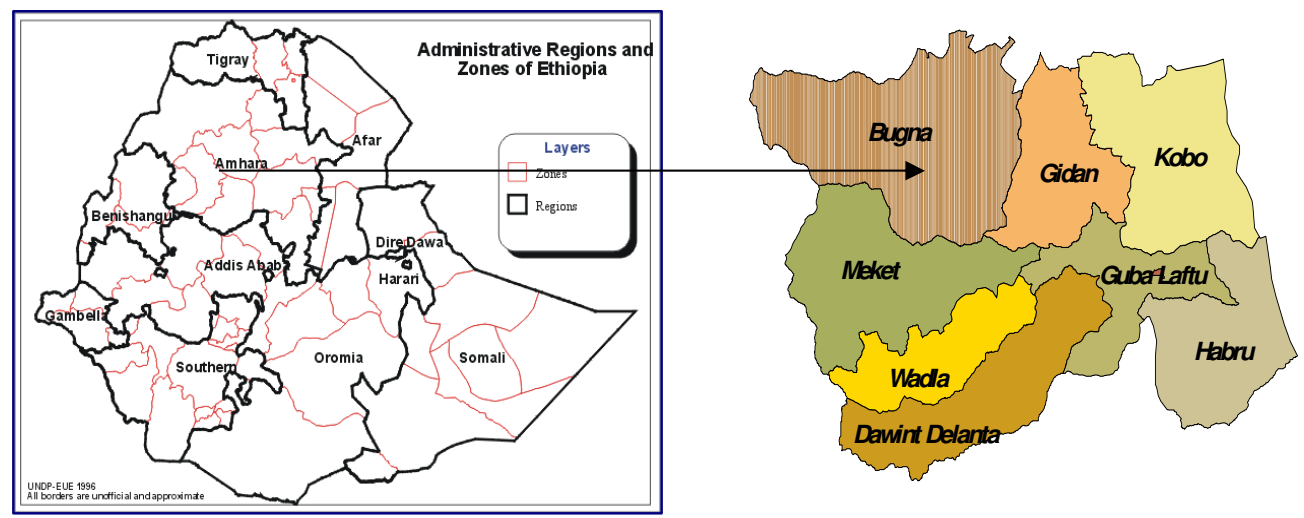

Figure 1.Location map of the study area

Mean monthly rainfall 2005

- long term average rainfall 1995-2005

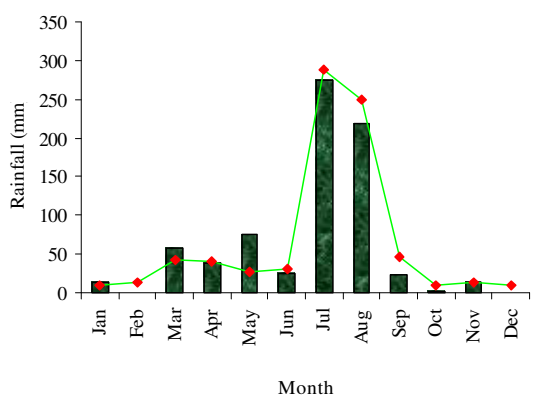

Figure 2. Rainfall distribution for the period of 1995-2005 of Dalenta Dawunt
^- maximum temperature -- minimum temperature

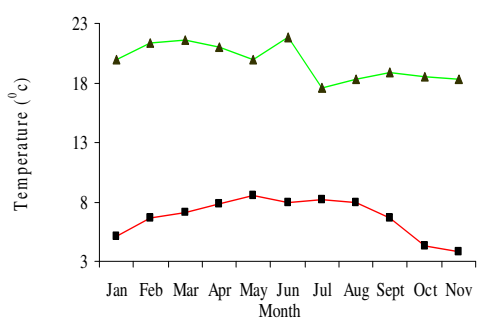

Figure 3. Monthly minimum and maximum temperature in 2005
The highland plateau areas have very cold temperature that ranges from $0^{0} \mathrm{C}$ to $20^{\circ} \mathrm{C}$ (Getaw et al, 2000). Asfaw and Amdemeskel (1998) reported that monthly average maximum temperature become high starting from December to May and then reduces significantly from September and October being the coldest months of the year. Besides, the minimum temperature recorded in this experimental year varied from $3.8^{0} \mathrm{C}$ in November to $8.5^{\circ} \mathrm{C}$ in May (Fig. 3).

\section{Soil types}

Table 1, showed the $\mathrm{pH}$ of these Vertisols as slightly acid. The chemical fertility is very poor and characterized by low Total. N, available P and exchangeable K. The 
clay content is generally quit high in distribution. The moisture storage of Vertisols ranged from 91.8 to $465.7 \mathrm{~mm}$ at field Experimental lay out

The experiment was conducted in 2005 cropping season in a randomized complete block design (RCBD) with three replicates. The treatments were flat seedbed (FSB), traditional drainage system, "Shurube" (TDS), broadbed and furrow with $100 \mathrm{~cm}$ bed and $50 \mathrm{~cm}$ furrow width by $30 \mathrm{~cm}$ bed height (BBF-100) and BBF with $80 \mathrm{~cm}$ bed and 40 $\mathrm{cm}$ furrow width by $20 \mathrm{~cm}$ bed height (BBF80). A partially water logging resistant local wheat variety was sown at the rate of $150 \mathrm{~kg}$ $\mathrm{ha}^{-1}$. Diammonium phosphate fertilizer was applied at a rate of $100 \mathrm{~kg} \mathrm{ha}^{-1}$ at sowing whereas urea was top dressed at $35^{\text {th }}$ day after sowing at the rate of $100 \mathrm{~kg} \mathrm{ha}^{-1}$.

\section{Plant data collection and analysis}

Dates during which $50 \%$ of the plant population reaches germination, tillering, stem elongation and anthesis and maturity were recorded. Plant height measurement was made using ruler in randomly selected five plots wherein samples were collected from seven quadrants. Plant density was measured at tillering; stem elongation and anthesis growth stages through direct counting. The length of spikes was measured using ruler. Weed infestation was studied by direct identification and counting within seven quadrants during tillering and stem elongation stages. Finally, data on wheat grains and dry matter were collected. Data collected were analysed using SAS (2002) and JMP-5.

\section{Soil moisture content measurement}

Soil moisture was measured in-situ using Time Domain Reflectometre (TDR) after installing access probe tubes to $100 \mathrm{~cm}$ depth in each plot so as to monitor water removal capability of each tillage practice. Then data were collected every other 10 days at depths of 0-20, 20-40-, 40-60, 60-80 and 80$100 \mathrm{~cm}$. Finally, JMP5 statistical software was used to analyze the data. capacity and 43.8 to $289.3 \mathrm{~mm}$ at permanent wilting point percentage (Table 2 ).

\section{Results and Discussions Tillage effects on yield component and yield of wheat Plant height}

Figure 4 showed the mean plant height at different growth stages, it compared the four treatments and the highest plant height was recorded on BBF-100 plot and followed by BBF-80 whereas the shortest plant was observed from control plot in all growth stage.

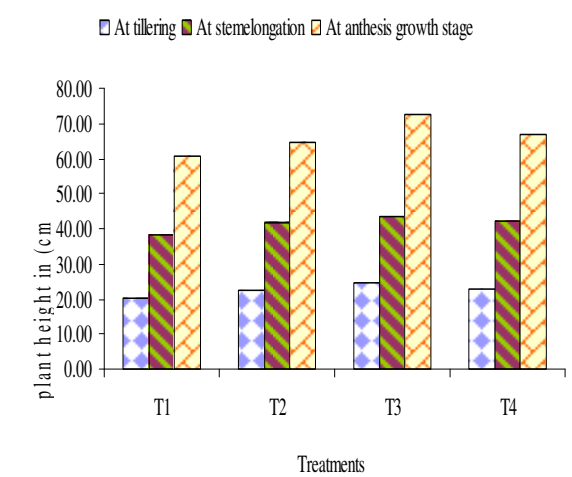

Figure 4.Tillage effect on plant height during the

growing cycle

The difference due to treatments in the height of wheat resulted in a significant effect at all stages of the growing cycle. However, the highest treatment mean observed at tillering, stem elongation and anthesis on BBF-100. In the contrary the lowest treatment mean was obtained from FSB at all growth stages (Table 3).

\section{Plant density}

Figure 5, revealed plant density at different growth stages. More tillers were from plot BBF-100 followed by TDS and BBF-80 at $50 \%$ tillering stage. Conversely, tillers from TDS plots were declined before reaching stem elongation and anthesis growth stages due to waterlogging. 


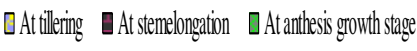

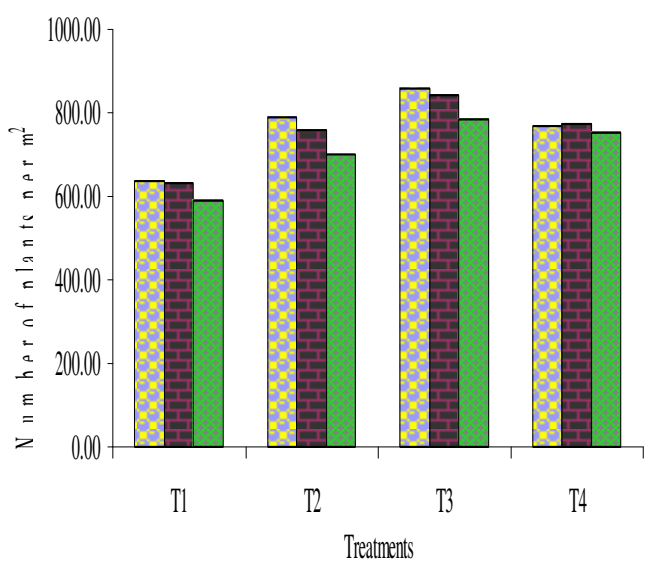

Figure 5. Cumulative plant densities at different growth stages

Although not significant, the highest density of wheat resulted in BBF-100 all growth stages when comparison was made amongst the treatment $\mathrm{T} 2$ and $\mathrm{T} 4$ but significant at $(\mathrm{p}<0.05)$ level with control plot (Table 4).

\section{Tillage effects on growth stages}

The study revealed that BBF- 80 and BBF-100 have instigated early germination but late maturity. In the contrary TDS caused shortening the duration to reach heading and maturity. Though BBF-100 was instrumental for causing the highest tiller number per quadrant and enhanced early germination, it extended the total length of the growing cycle due to delaying heading and maturity (Table5). This is probably due to the largest amount water stored in the beds of the furrow (Table 2). As is shown in Table 5, tillage has significantly affected the length of days required for germination and to reach maturity but it insignificantly affected the length of days to reach heading. It was observed that about two and a half-months elapsed to reach heading.

\section{Spike length}

Though the ANOVA did prove the non-significant effect of tillage on the length of spike, the longest and shortest spike lengths were obtained from BBF-100 and FSB plots, respectively (Table 6).

\section{Dry matter yield}

The mean grain and straw yields of wheat was significantly affected (p0.05) by different tillage practices. When comparison was made among the treatments, significantly higher straw yield value was observed in $\mathrm{BBF}$ treatments (T3\& T4) and non- significantly higher straw yield was observed on traditional drainage system as compared to control. The difference due to treatments resulted in a significant effect on the straw weight during cropping season. The lowest weight of straw was resulted in control plot (Table 7). Several authors had reported increased yields of some crop grown on Vertisols due to the use of BBF as compared to flat seedbeds (Abiye et al., 1995; Srivastava et al., 1993; Teklu et al., 2006).

\section{Grain yield}

BBF with $100 \mathrm{~cm}$ beds gave the highest mean grain yield of wheat. Yield increased by $51.44 \%$ as compared to the control plot (Table 7). The grain yield was also significantly increased in BBF $80 \mathrm{~cm}$ beds and traditional drainage system $41.6 \%$ and $11.2 \%$ as compared to control plot respectively. Although not significant, BBF T3 gave the highest 1000 -grain weight g resulting $35.4 \mathrm{~g}$ as compared to the control. The treatment mean value indicates that the highest weight of straw, grain and 1000 grain was resulted in BBF T3 but the lowest weight of straw, grain and 1000 grain was recorded in the control plot (Table 7).

\section{Tillage effect on soil water contents}

Although not significant relation was observed among the treatment, the highest mean moisture content at the depths of 60-80 $\mathrm{cm}$ and $80-100 \mathrm{~cm}$ at anthesis growth stage as compared 0-20 cm depth in all tillage practices (Table 8). As is shown in Table 8, differences due to treatments on different soil layer resulted in a non significance (p0.05) on moisture content. Also in Table 2 the highest moisture content was obtained from FSB and BBF-100 whereas the lowest were in BBF-80 followed by TDS at $0-20 \mathrm{~cm}$ depth during 
early rain in the season late July and August. The tillage practice did not have a significant effect on soil moisture within the depth of 0 to $100 \mathrm{~cm}$ during the rainy season (Table 8). In late July until end of August $45.1 \%$ the mean soil moisture for $0-20 \mathrm{~cm}$ depth was comparatively higher than for $0-20 \mathrm{~cm}$ depth early September to late November $33.3 \%$. At the surface $(0-20 \mathrm{~cm}$ depth $)$ of the soil, the maximum moisture content was observed in late July and end of August and the least were in September to November.

\section{Soil moisture characterization in different soil layer}

Table 9, showed moisture storage variations in the study area at field capacity and permanent wilting points was ranging from 91.9 to 465.7 and 43.8 to $289.3 \mathrm{~mm}$, respectively whereas the available moisture storage was varied from 48 to $176.4 \mathrm{~mm}$.

\section{Conclusion and recommendations}

This study revealed that BBF-100 favored better plant height, density, spike length and eventually dry matter and grain yield formation than the other treatments. BBF-100 did increase the grain yield by 51.4 $\%$ as compared to the control plot. Promising results were found in BBF-80 in which the grain yield was also increased by $41.6 \%$ over the control. The impact of BBF-100 and BBF80 has been proved by the cost benefit analysis. Cost to benefit ratio was computed for the four tillage practices and higher ratio was obtained from BBF-100 and BBF-80 plots. Hence, based on the agronomic effect and cost to benefit analysis, this study recommends the use of BBF-100 followed by BBF-80 in water logging prone areas of the central highlands of Ethiopia.

\section{Reference}

Abate Tedla, Sherington, J, and Mohamed Saleem, M.A.(1993). Integration of forage and food crops grown sequentially on Vertisols under rain fed conditions in the mid altitude Ethiopian high lands ILCA, Addis Ababa.

Abiye, A., Muhamed-Saleem, M.A., ElWakeel, A. (1995). Soil water dynamics under cereal and forage legume mixtures on drained Vertisols in the Ethiopian highlands. Agric. Water Manage.

ANRS ARDB.(2005). Department of Agronomy and Protection -the training manual for regional Vertisol management for development agent November, 2005 Bahar Dar.

Berhanu, D. (1985). The Vertisols of Ethiopia: their properties, classification and management. In: Fifth Meeting of the Eastern African Soil Correlation and Land Evaluation Sub-committee, 4-10 December, 1985. Wad Medani. World Soil Resources Report 56. FAO.

Berhanu Debele (2000). Management of Vertisols and catchments treatment on Delanta Dawunt plateau, North Wollo prepared for Oxfam -GB Addis Ababa, May, 2000.

Getaw Tadesse et al (2000). Farming systems of Delanta Dawunt Woreda and FPR (Farmers Participatory Research) Interventions: Result of field visits and research proposal. Sirinka Agricultural Research Center in collaboration with Oxfam_GB.

Jutzi S C, Haque I, McIntire J and Stares J E S (1987) (eds). Management of Vertisols in sub Saharan Africa. Proceedings of a conference held at ILCA, Addis Ababa, Ethiopia, and 31August-4 September 1987. ILCA, Addis Ababa, Ethiopia.

Lakew Desta, Carrucci, V, Asrat Wendemagene and Yitayew Abebe (2005). Community based participatory watershed development: a Guideline Ministry of agriculture and Rural Development Addis Ababa, Ethiopia.

Srivastava, K.L., Abiye Astatke, Tekalign Mamo, Hailu Regassa and Selamyihun Kidanu (1993). Land, Soil and Water management. In: Improved management of Vertosols for sustainable crop-livestock production in the Ethiopian highlands: Synthesis report 1986-92 (by Tekalign Mamo, Abiye Astatke, K.L. Srivastava, Asgelil Dibabe). Technical committee of the joint Vertisol project, Addis Ababa, Ethiopia.

Teklu Erkossa, Karl Stahr, Thomas Gaiser (2006) Soil tillage and crop productivity on a Vertisol in Ethiopia highlands: Soil tillage research 85 
Table 1. Physico-chemical characteristics of Vertisols in the study area

\begin{tabular}{|c|c|c|c|c|c|c|c|c|c|c|}
\hline $\begin{array}{c}\text { Depth } \\
\text { (cm) }\end{array}$ & $\begin{array}{l}\text { pH } \\
\mathrm{H}_{2} \mathrm{O} \\
\end{array}$ & $\begin{array}{l}\text { OC } \\
\% \\
\end{array}$ & N \% & $\begin{array}{l}\text { P } \\
\text { ppm }\end{array}$ & $\begin{array}{l}\text { K } \\
\text { me/100g }\end{array}$ & $\begin{array}{l}\text { CEC } \\
\mathrm{me} / 100 \mathrm{~g}\end{array}$ & Clay & Sand & Silt & $\begin{array}{l}\text { Textural } \\
\text { class } \\
\text { name } \\
\end{array}$ \\
\hline $0-20$ & 6.7 & 0.86 & 0.08 & 2.5 & 1.1 & 37 & 68 & 25 & 7 & Clay \\
\hline $20-40$ & 6.5 & 0.87 & 0.07 & 1.7 & 1.6 & 40 & 73 & 23 & 4 & Clay \\
\hline $40-60$ & 6.5 & 0.83 & 0.08 & 1.4 & 1.5 & 37 & 72 & 23 & 5 & Clay \\
\hline $60-80$ & 6.5 & 0.88 & 0.08 & 1.5 & 1.1 & 36 & 72 & 23 & 5 & Clay \\
\hline $80-100$ & 6.4 & 0.72 & 0.07 & 1.5 & 0.9 & 37 & 71 & 23 & 6 & Clay \\
\hline
\end{tabular}

Table 2. Moisture storage at different depth in the study area

\begin{tabular}{lllllllll}
$\begin{array}{l}\text { Soil } \\
\text { depth }\end{array}$ & Thickness & $\begin{array}{l}\text { FC at } \mathbf{0 . 3 3} \\
\text { bar } \\
\text { tension }\end{array}$ & $\begin{array}{l}\text { PWP at } \\
\mathbf{1 5} \\
\text { bar } \\
\text { tension }\end{array}$ & AW & \multicolumn{2}{c}{ Moisture storage (mm) } \\
& $(\mathbf{m m})$ & FC & PWP & AW \\
\hline $0-20$ & 200 & 45.9 & 21.9 & 48.1 & 91.8 & 43.8 & 48.1 \\
$20-40$ & 200 & 46.5 & 29.9 & 33.2 & 184.9 & 103.6 & 81.3 \\
$40-60$ & 200 & 53.0 & 36.2 & 33.8 & 290.9 & 175.9 & 115.0 \\
$60-80$ & 200 & 48.7 & 26.9 & 43.4 & 388.3 & 229.9 & 158.4 \\
$80-100$ & 200 & 38.7 & 29.7 & 17.9 & 465.7 & 289.3 & 176.4 \\
\hline
\end{tabular}

Table 3.Tillage practices effect on wheat height

\begin{tabular}{|c|c|c|c|}
\hline \multirow[t]{2}{*}{ Treatment } & \multicolumn{3}{|c|}{ Mean of plant height (cm) } \\
\hline & Tillering & Stem elongation & Anthesis \\
\hline $\mathrm{T} 1$ & $20.2 c$ & $38.1 \mathrm{~b}$ & $60.8 b$ \\
\hline T2 & $22.3 b$ & $41.9 \mathrm{ab}$ & $64.7 \mathrm{ab}$ \\
\hline T3 & $24.5 \mathrm{a}$ & $43.6 \mathrm{a}$ & $72.4 \mathrm{a}$ \\
\hline T4 & 23.0ab & $42.0 \mathrm{ab}$ & $66.8 \mathrm{ab}$ \\
\hline (p0.05) & * & $*$ & $*$ \\
\hline $\mathrm{CV} \%$ & 7.61 & 5.89 & 7.38 \\
\hline
\end{tabular}

$\mathrm{NS}=$ non-significant $*=$ the difference is significant at $(\mathrm{p}<0.05)$ level

Levels not connected by same letter are significantly different

\begin{tabular}{llll}
\multicolumn{2}{l}{ Table 4.Tillage effect on density of wheat } & & \\
\hline Treatment & $\begin{array}{c}\text { Mean of plant density } \\
\text { Tillering }\end{array}$ & Stem elongation & Anthesis \\
\hline $\mathrm{T} 1$ & $639.3 \mathrm{~b}$ & $633 . \mathrm{b}$ & $591.0 \mathrm{c}$ \\
$\mathrm{T} 2$ & $789.67 \mathrm{a}$ & $758.33 \mathrm{a}$ & $698.3 \mathrm{~b}$ \\
$\mathrm{~T} 3$ & $860.33 \mathrm{a}$ & $841 \mathrm{a}$ & $783.0 \mathrm{a}$ \\
$\mathrm{T} 4$ & $769.33 \mathrm{a}$ & $774.3 \mathrm{a}$ & $752.3 \mathrm{ab}$ \\
$(\mathrm{p} 0.05)$ & $*$ & $*$ & $*$ \\
$\mathrm{CV} \%$ & 11.9 & 11.38 & 11.38 \\
\hline
\end{tabular}

$\mathrm{NS}=$ non-significant $*=$ the difference is significant at $(\mathrm{p}<0.05)$ level

Levels not connected by same letter are significantly different

Table 5.Tillage practices effect on agronomic parameter

\begin{tabular}{llll}
\hline Treatment & $\begin{array}{l}\text { Mean of days to } \\
\text { Germination }\end{array}$ & Heading & Maturity \\
\hline $\mathrm{T} 1$ & $5.7 \mathrm{a}$ & $78.3 \mathrm{a}$ & $121.67 \mathrm{~b}$ \\
$\mathrm{~T} 2$ & $5 \mathrm{ab}$ & $70.7 \mathrm{a}$ & $118.0 \mathrm{~b}$ \\
$\mathrm{~T} 3$ & $4 \mathrm{bc}$ & $79.0 \mathrm{a}$ & $129.33 \mathrm{a}$ \\
$\mathrm{T} 4$ & $3.7 \mathrm{c}$ & $76.0 \mathrm{a}$ & $122.33 \mathrm{~b}$ \\
$(\mathrm{p} 0.05)$ & $*$ & $\mathrm{NS}$ & $*$ \\
$\mathrm{CV} \%$ & 19.64 & 5.64 & 3.82 \\
\hline
\end{tabular}

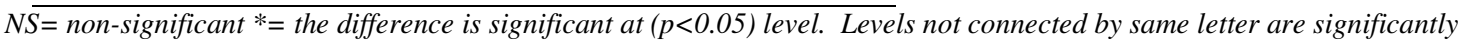
different 
Table 6. Tillage effect on the spike length yield of wheat

\begin{tabular}{ll}
\hline Treatment & Mean spike length $(\mathrm{cm})$ \\
\hline $\mathrm{T} 1$ & $6.40 \mathrm{a}$ \\
$\mathrm{T} 2$ & $6.77 \mathrm{a}$ \\
$\mathrm{T} 3$ & $7.83 \mathrm{a}$ \\
$\mathrm{T} 4$ & $7.27 \mathrm{a}$ \\
$\mathrm{p} 0.05)$ & $\mathrm{NS}$ \\
$\mathrm{CV} \%$ & 11.02 \\
\hline
\end{tabular}

$N \overline{S=\text { non-significant } *=\text { the difference is significant at }(p<0.05) \text { level. }}$.

Levels not connected by same letter are significantly different

Table 7.Tillage effect on wheat dry matter and grain yield

\begin{tabular}{|c|c|c|c|c|c|}
\hline Treatments & $\begin{array}{l}\text { Straw yield } \\
\mathrm{kg} / \mathrm{ha}\end{array}$ & $\begin{array}{l}\text { Mean Grain } \\
\text { yield t/ha }\end{array}$ & $\begin{array}{l}1000 \text { grain } \\
\text { wt (g) }\end{array}$ & $\begin{array}{l}\% \text { Increa } \\
\text { Straw } \\
\text { yield \% }\end{array}$ & ver control \\
\hline $\mathrm{T} 1$ & $2056.03 \mathrm{c}$ & $1.25 \mathrm{c}$ & $31.50 \mathrm{a}$ & & \\
\hline $\mathrm{T} 2$ & $2474.13 b c$ & $1.39 \mathrm{~b}$ & $33.17 \mathrm{a}$ & 20.34 & 11.18 \\
\hline $\mathrm{T} 3$ & $3090.06 \mathrm{a}$ & $1.89 \mathrm{a}$ & $35.30 \mathrm{a}$ & 50.3 & 51.44 \\
\hline $\mathrm{T} 4$ & $2797 \mathrm{ab}$ & $1.77 \mathrm{a}$ & $34.50 \mathrm{a}$ & 36 & 41.6 \\
\hline (p0.05) & $*$ & $*$ & NS & & \\
\hline $\mathrm{Cv} \%$ & 16.41 & 17.63 & 6.60 & & \\
\hline
\end{tabular}

Table 8.Tillage practice effect on soil water

\begin{tabular}{|c|c|c|c|c|c|c|c|c|c|c|}
\hline \multirow[b]{3}{*}{ Treatment } & \multicolumn{10}{|c|}{ Depth of profile (cm) } \\
\hline & \multicolumn{2}{|c|}{$0-20$} & \multicolumn{2}{|c|}{$20-40$} & \multicolumn{2}{|c|}{$40-60$} & \multicolumn{2}{|c|}{$60-80$} & \multicolumn{2}{|c|}{$80-100$} \\
\hline & Mean & Std Dev & Mean & Std Dev & Mean & Std Dev & Mean & $\begin{array}{l}\text { Std } \\
\text { Dev }\end{array}$ & Mean & $\begin{array}{l}\text { Std } \\
\text { Dev }\end{array}$ \\
\hline $\mathrm{T} 1$ & $32.1 \mathrm{a}$ & 13.79 & $34.4 \mathrm{a}$ & 18.21 & $32.9 a$ & 19.17 & $47.1 \mathrm{a}$ & 5.21 & $43.5 a$ & 7.03 \\
\hline $\mathrm{T} 2$ & $25.0 \mathrm{a}$ & 16.15 & $34.1 \mathrm{a}$ & 16.58 & $33.4 \mathrm{a}$ & 17.76 & $45.9 \mathrm{a}$ & 4.99 & $43.6 \mathrm{a}$ & 6.92 \\
\hline T3 & $30.8 \mathrm{a}$ & 17.82 & $35.6 \mathrm{a}$ & 15.70 & $36.2 \mathrm{a}$ & 15.91 & $46.8 \mathrm{a}$ & 3.45 & $45.5 a$ & 5.91 \\
\hline $\mathrm{T} 4$ & $24.7 \mathrm{a}$ & 17.41 & $33.4 \mathrm{a}$ & 16.95 & $34.2 \mathrm{a}$ & 16.15 & $45.2 \mathrm{a}$ & 4.58 & $44.4 \mathrm{a}$ & 5.69 \\
\hline (p0.05) & NS & & NS & & NS & & NS & & NS & \\
\hline $\mathrm{CV}(\%)$ & 58.5 & & 48.9 & & 50.31 & & 9.97 & & 14.4 & \\
\hline
\end{tabular}

$N S=$ non-significant $*=$ the difference is significant at $(p<0.05)$ level

Table 9. Moisture storage at different depth in the study area

\begin{tabular}{llllllll}
$\begin{array}{l}\text { Soil } \\
\text { depth }\end{array}$ & $\begin{array}{l}\text { Thickness } \\
(\mathbf{m m})\end{array}$ & $\begin{array}{l}\text { FC at } \mathbf{0 . 3 3} \\
\text { Bar tension }\end{array}$ & $\begin{array}{l}\text { PWP at 15 } \\
\text { bar tension }\end{array}$ & $\begin{array}{l}\text { AW } \\
(\mathbf{m m})\end{array}$ & $\begin{array}{l}\text { Storage } \\
\text { FC }\end{array}$ & PWP & AW \\
\hline $0-20$ & 200 & 45.9 & 21.9 & 48.1 & 91.8 & 43.8 & 48.1 \\
$20-40$ & 200 & 46.5 & 29.9 & 33.2 & 184.9 & 103.6 & 81.3 \\
$40-60$ & 200 & 53.0 & 36.2 & 33.8 & 290.9 & 175.9 & 115.0 \\
$60-80$ & 200 & 48.7 & 26.9 & 43.4 & 388.3 & 229.9 & 158.4 \\
$80-100$ & 200 & 38.7 & 29.7 & 17.9 & 465.7 & 289.3 & 176.4 \\
\hline
\end{tabular}

